\title{
A Case of Solitary Fibrous Tumor in the External Auditory Canal
}

\author{
Kyuha Shin $^{1} \mathbb{D}$, Juchang Kang ${ }^{1} \mathbb{D}$, Kyewon Kwon ${ }^{2}$, and Yunsuk An $^{1} \mathbb{C}$ \\ ${ }^{1}$ Departments of Otorhinolaryngology-Head and Neck Surgery, ${ }^{2}$ Pathology, Bundang Jesaeng General Hospital, Daejin Medical Center, \\ Seongnam, Korea
}

외이도의 고립성 섬유종 1 예

신규하 ${ }^{1} \cdot$ 강주창 $^{1} \cdot$ 권계원 ${ }^{2} \cdot$ 안윤숙 $^{1}$

대진의료재단 분당제생병원 이비인후-두경부외과, ${ }^{1}$ 병리과 ${ }^{2}$

\author{
Received May 21, 2020 \\ Revised July 13, 2020 \\ Accepted July 17, 2020 \\ Address for correspondence \\ Yunsuk An, MD, PhD \\ Department of Otorhinolaryngology- \\ Head and Neck Surgery, \\ Bundang Jesaeng General Hospital, \\ Daejin Medical Center, \\ 20 Seohyeon-ro 180beon-gil, \\ Bundang-gu, Seongnam 13590, \\ Korea \\ Tel +82-31-779-0258 \\ Fax +82-31-779-0265 \\ E-mail stella0423@hotmail.com
}

Solitary fibrous tumor (SFT) is a rare benign spindle-cell neoplasm, most often found in the pleura. Recently, it has been reported to appear throughout the body but rarely in head and neck region. Tumors in the external auditory canal, in particular, have been very rarely reported. We experienced a case of a 55-year-old male with a 6-month history of progressive swelling from the orifice of left external auditory canal. The tumor was round, well circumscribed, almost completely obstructing the left external auditory canal. On the enhanced temporal bone $\mathrm{CT}$ and enhanced paranasal sinus MRI, a $2.0 \times 1.7 \mathrm{~cm}$ sized mass was observed at the left external auditory canal. He was treated with surgical excision under general anesthesia. Histopathologic examination confirmed the diagnosis of SFT. This case report presents a rare case of a SFT arising in the external auditory canal.

Korean J Otorhinolaryngol-Head Neck Surg 2020;63(11):523-7

Key Words External auditory canal · Mesenchymal tumor · Solitary fibrous tumor.

\section{서 론}

고립성 섬유종(solitary fibrous tumor, SFT)은 주로 흉막의 간엽세포에서 기원하는 드문 양성 방추세포 종양으로(mesenchymal tumor) 1931년 Klemperer와 Rabin ${ }^{1)}$ 이 처음으로 보고하였다.

흥막 외에도 복강, 종격동, 폐, 간, 신장 등 신체 전반에서 발생할 수 있으며, ${ }^{2)}$ 두경부 영역에서는 구강, 비강, 눈, 후두, 갑상선, 침샘, 부인두강 등에서 발생한다. ${ }^{3)}$ 이중 외이도에서 발생하는 경우는 국외 4예, 국내 1예로 매우 드물게 보고되었 다(Table 1)

고립성 섬유종은 조직학적 검사를 통해 진단하며, 이에 감

This is an Open Access article distributed under the terms of the Creative Commons Attribution Non-Commercial License (https://creativecommons.org/licenses/by-nc/4.0) which permits unrestricted non-commercial use, distribution, and reproduction in any medium, provided the original work is properly cited.
별해야 할 질환으로는 신경섬유종, 신경초종, 섬유육종, 혈관 주위세포종 등이 있다. ${ }^{4)}$ 현재까지 외이도에서 발생한 고립성 섬유종은 매우 드물어 그 특성을 논의하긴 어려우나, 흉막 외 고립성 섬유종의 특성을 고려해본다면 악성 및 재발 가능 성이 있으므로,5) 가능하면 수술적으로 완전히 절제되어야 한다. ${ }^{4}$

본 저자들은 55세 남환의 외이도에 발생한 고립성 섬유종 1 예를 경험하였기에 이를 문헌 고찰과 함께 보고하고자 한다.

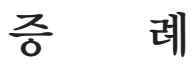

55세 남자 환자가 우연히 발견된 좌측 외이도의 종물을 주 소로 내원하였다. 환자는 문진에서 이충만감을 호소하였고, 난청, 이명, 이통, 어지럼증 등의 다른 이과적 증상은 호소하 지 않았다. 과거력상 고혈압 외에 가족력 및 사회력상 특이 
사항은 없었다. 이학적 검사상 좌측 외이도를 완전히 메우는 종물이 외이도 입구의 후벽에서 관찰되었으며, 종물은 비교 적 단단하였고, 경계가 분명하였다(Fig. $1 \mathrm{~A})$. 고막은 종물로 인하여 확인이 어려웠고, 순음청력검사에서 6 분법상 우측은 $10 \mathrm{~dB} \mathrm{HL}$, 좌측은 $17 \mathrm{~dB} \mathrm{HL}$, 어음변별력검사상 우측은 $100 \%$, 좌측은 $92 \%$ 확인되었다.

전산화단층촬영 영상에서 조영제 투여시 불균일하게 조영 증강을 보이며, 경계가 분명한 $2.0 \times 1.7 \mathrm{~cm}$ 크기의 종물이 좌 측 외이도에 위치하고 있었고, 외이도가 매우 좁아진 소견이 었다(Fig. 2A and B). 자기공명영상에서도 좌측 외이도에 종 물이 확인 되었고, 조영제 투여시 불균일한 조영 증강을 보였
다. 또한 주변 조직으로의 침범이나 변형은 보이지 않았다 (Fig. 2C and D). 초음파 유도하 세침흡인검사를 시행하였고, 종물에서 비전형적인 세포는 보이지 않았으며, 섬유 조직(fibrous tissue)이 확인되었다.

전신 마취하 미세수술 현미경을 이용하여 후이개 접근법으 로 종물을 절제하였다(Fig. $3 \mathrm{~A}$ ). 육안 소견상 $2.3 \times 2 \times 1.5 \mathrm{~cm}$ 크기의 경계가 명확한 연조직 종물이 확인되었다(Fig. $3 \mathrm{~B}$ ). 수술적 완전 절제 후 귀 패킹을 시행하였다. 환자는 수술 후 1 일째, 특별한 합병증 없이 퇴원하였다.

병리조직검사상 전체 검체의 단면은 회백색으로 경계가 명 확하였고(Fig. 4A), 방추세포(spindle cell)가 많은 지역과 세

Table 1. Cases review of solitary fibrous tumor in external auditory canal previously reported

\begin{tabular}{|c|c|c|c|c|c|c|c|c|c|}
\hline Author & Year & Sex & Age & e Chief complaint & Size $(\mathrm{cm})$ & Treatment & $\begin{array}{c}\mathrm{F} / \mathrm{U} \\
\text { month }\end{array}$ & Complication & Recurrence \\
\hline $\begin{array}{l}\text { Izumaru, } \\
\text { et al. }\end{array}$ & 1997 & Male & 38 & Decreased hearing & $\begin{array}{l}1.0 \times 1.5 \times \\
1.5 \mathrm{~cm}\end{array}$ & Surgical excision & - & No & No \\
\hline Rezk, et al. ${ }^{5)}$ & 2006 & Female & 39 & Decreased hearing & $\begin{array}{l}1.7 \times 1.1 \times \\
0.6 \mathrm{~cm}\end{array}$ & Tympanomastoidectomy & - & No & No \\
\hline Lee, et al. ${ }^{7)}$ & 2008 & Female & 25 & $\begin{array}{l}\text { Progressive swelling, } \\
\text { bleeding }\end{array}$ & $\begin{array}{l}2.0 \times 1.8 \times \\
1.5 \mathrm{~cm}\end{array}$ & Surgical excision & 24 & No & No \\
\hline $\begin{array}{l}\text { Yuzawa, } \\
\text { et al. }\end{array}$ & 2016 & Female & 31 & No & $1.8 \mathrm{~cm}$ & Surgical excision & & No & No \\
\hline $\begin{array}{l}\text { Jefferson, } \\
\text { et al. }{ }^{9)}\end{array}$ & 2019 & Female & 60 & $\begin{array}{l}\text { Progressive swelling, } \\
\text { intermittent } \\
\text { suppuration and } \\
\text { decreased } \\
\text { hearing }\end{array}$ & $2 \times 2 \times 1 \mathrm{~cm}$ & Surgical excision & 24 & No & No \\
\hline
\end{tabular}

F/U: follow up
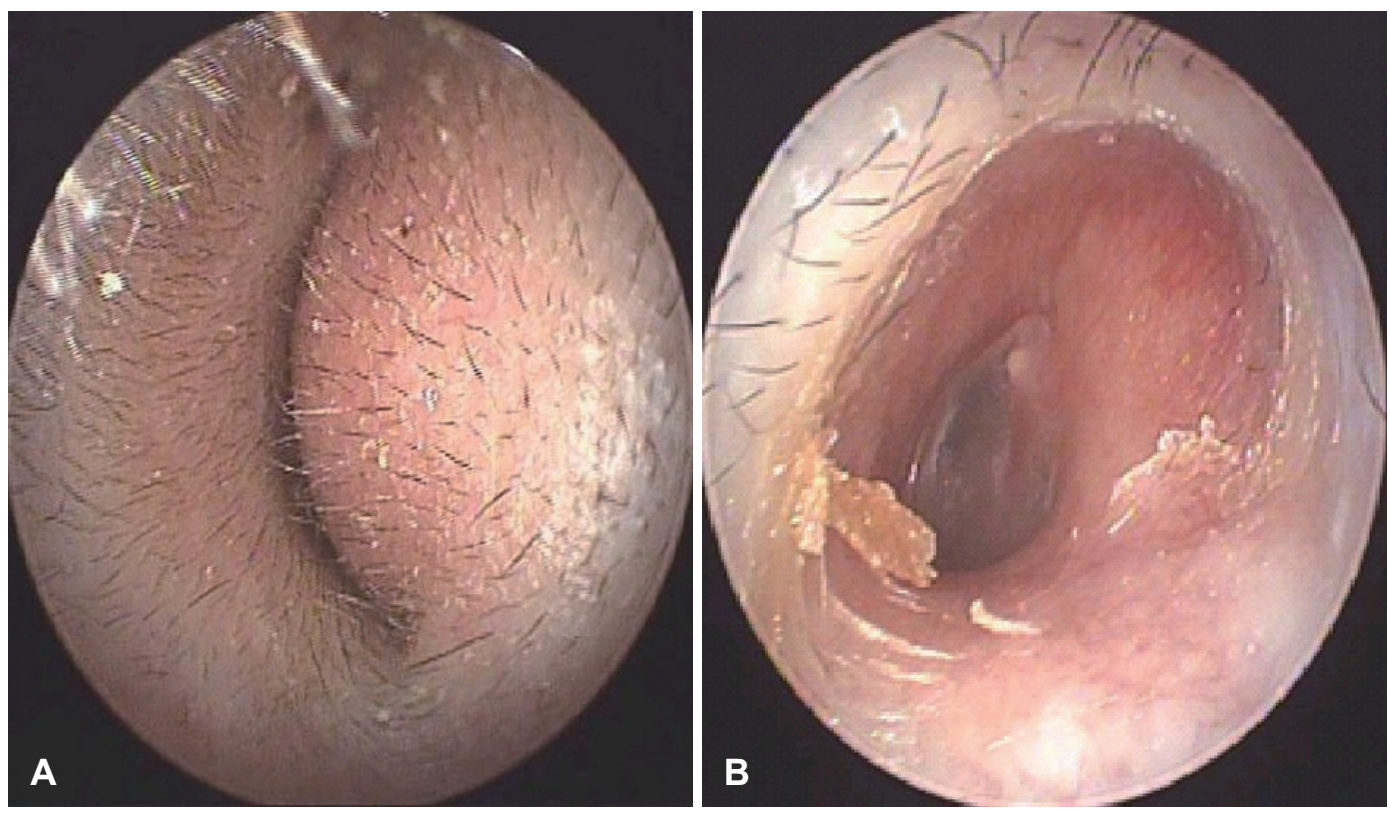

Fig. 1. Preoperative and postoperative otoendoscopic findings of left external auditory canal. A small round, well skin covered mass was observated on the posterior wall with obstructing the entrance of left external auditory canal (A). Otoendoscopic finding shows no sign of recurrence in the postoperative site at 9 months follow-up (B). 
포가 적고 섬유질로 채워진 지역들이 불규칙한 형태로 나타 났으며, 사슴뿔 모양의 혈관들이 함께 관찰되었다(Fig. 4B). 또한 단조로운 핵을 가진 섬유아세포와 교원성기질이 혼재
된 양상을 보였고(Fig. 4C), 면역조직화학염색(immunohistochemical stain)에서 CD34에 양성 반응을 나타내어(Fig. 4D), 고립성 섬유종으로 진단하였다. 환자는 수술 후 9개월
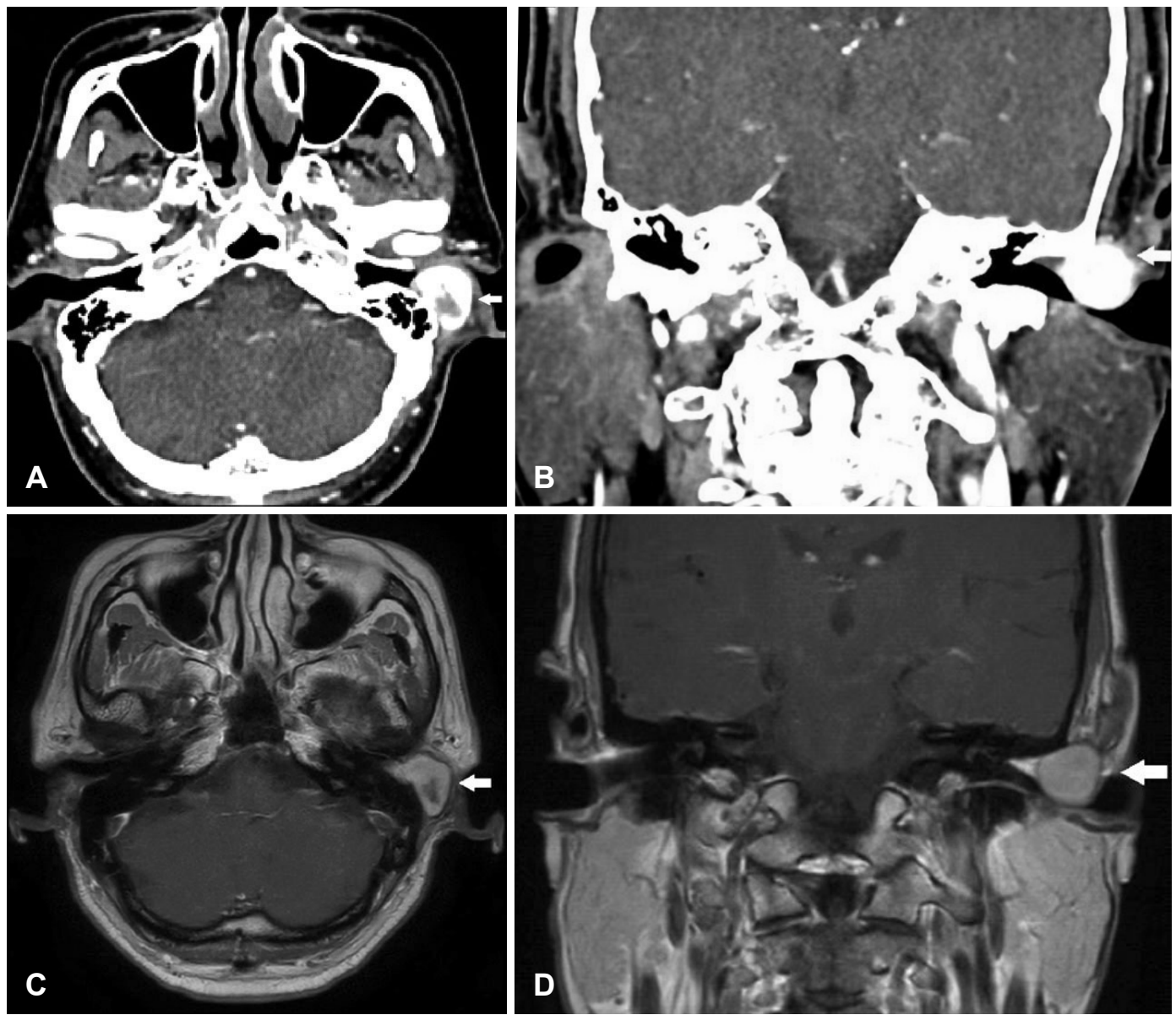

Fig. 2. Enhanced temporal bone CT and enhanced paranasal sinus MRI scans of the mass. Axial (A) and coronal (B) contrast-enhanced temporal CT image shows that a $2.0 \times 1.7 \mathrm{~cm}$ sized highly enhancing heterogeneous well-defined mass (arrow) in the left external auditory canal without bony erosion. Axial (C) and coronal (D) Enhanced paranasal sinus T1-weighted MR image shows that a $2.0 \times 1.7 \mathrm{~cm}$ sized mass (arrow) with central low signal intensity and peripheral enhancement in the left external auditory canal.
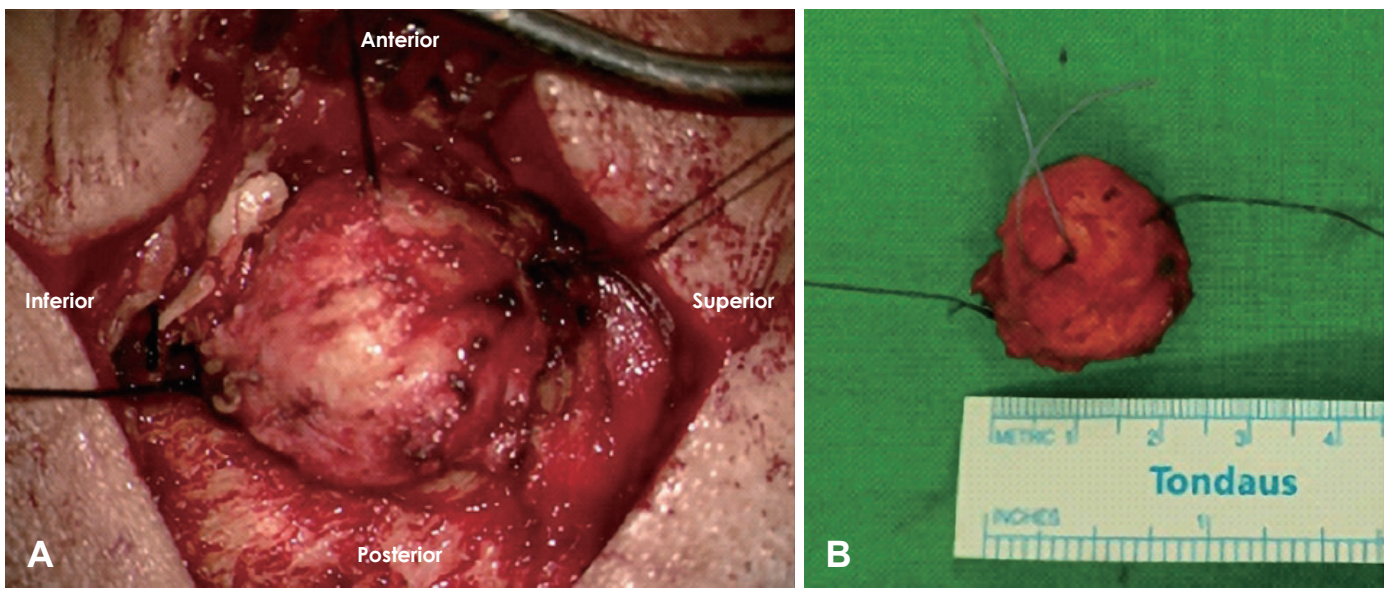

Fig. 3. Operative views. Intraoperative surgical view extirpating of tumor from left external auditory canal (A). Surgical exploration showed a well circumscribed soft tissue mass of $2.3 \times 2 \times 1.5 \mathrm{~cm}(\mathrm{~B})$. 

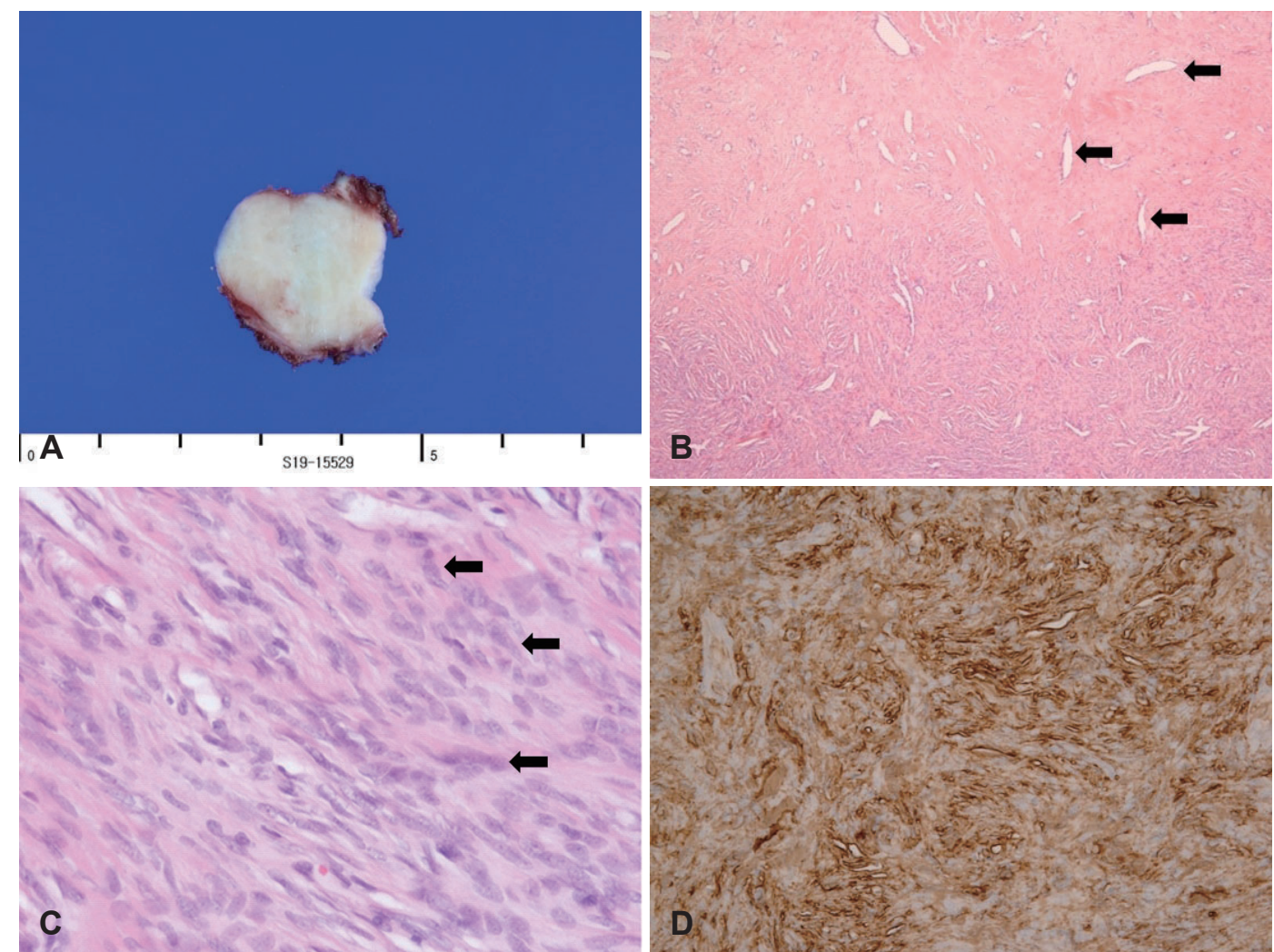

Fig. 4. Histological and immunohistochemical findings of solitary fibrous tumor. The gross specimen shows well circumscribed mass with gray-white, firm cut surface (A). The tumor had a patternless architecture of hypo- and hypercellular areas separated by thick, hyalinized collagen with cracking artifact and staghorn vessels (arrows) (B) (H\&E, $\times 40)$. Fibroblast-like cells with bland nuclear features (arrows), mixed with collagenous stroma $(C)(H \& E, \times 400)$. The tumor cells demonstrate immunoreactivity for CD34 (D) (immunochemistry, original magnification $\times 200)$. H\&E: hematoxylin and eosin.

동안 재발 소견 없이 경과 관찰 중이다(Fig. 1B).

\section{고 찰}

고립성 섬유종(SFT)은 대부분 중년에서 주로 발생하며, 남 녀 유병률은 비슷하다.) 대부분의 경우 증상은 없으나 발생되 는 위치나 크기에 따라 국소적 증상을 보이는 경우도 있다.)

이제까지 보고된 증례에서, 외이도에서 발생한 고립성 섬 유종 환자의 대부분은 외이도 폐쇄로 인한 청력감소를 주로 호소 하였으며, 증상이 없는 경우도 있었다(Table 1). 본 증례 에서 환자는 좌측 이충만감으로 내원하였으며, 청력감소를 호 소하지는 않았다. 순음청력검사상 좌측 $17 \mathrm{~dB}$ 로 우측 $10 \mathrm{~dB}$ 에 비해 고주파 영역에서 청력 역치의 상승 소견이 보이나, 이 는 종물로 인한 가능성은 떨어지는 것으로 생각된다.

고립성 섬유종은 다른 연조직 종양과 영상학적 검사 결과 가 유사하여 진단을 위한 특징적인 소견은 없다. 전산화단층 촬영 영상에서는 저음영 종물로 보이고, 조영제 투여시 불균 일하게 조영 증강을 보이며, 종물의 압력으로 인한 골파괴의 소견이 동반되기도 한다. ${ }^{10}$ 또한, 자기공명영상의 $\mathrm{T} 1$-강조영
상에서는 경계가 뚜렷한 종물이 근육과 동등한 신호강도로 나타나거나 저강도 신호로 나타나며, T2-강조영상에서 저신 호강도 및 고신호강도가 불규칙하게 나타나고, 조영제 투여 시 불균일한 조영 증강을 보인다.10)

고립성 섬유종의 조직학적 소견은 진단에 있어서 중요하다. 현미경 검사상 종물의 경계가 명확하고, 방추형 세포와 교원 질이 불규칙하게 배열된 특징이 있다.) 면역조직화학염색에서 특징적으로 $\mathrm{CD} 34$ 항원에 양성반응을 보이며, 그 외에도 vimentin, bcl-2 등에 양성반응을 보이고, cytokeratine, S-100 protein, desmin, muscle-specific actin, smooth-muscle actin에는 대부분 음성반응을 보인다.) 이 염색 방법을 통해 방추세포를 가지는 다른 연부 조직 종양과 감별할 수 있고, 이에 감별해야 할 질환으로 신경섬유종, 신경초종, 섬유육종, 혈관주위세포종 등이 있다. ${ }^{4}$ 본 증례에서는 면역조직화학염 색(immunohistochemical stain)에서 CD34에 양성, S-100 protein 음성, C-kit 음성, desmin 음성, actin 음성, EMA 음 성으로 나타내어 고립성 섬유종으로 진단하였다.

고립성 섬유종은 대부분 양성이나, 드물게 악성이 발생하는 경우도 있다. ${ }^{11)}$ Chan은 조직 소견상 높은 세포충실성(cellu- 
arity), 세포다형성(pleomorphism), 높은 유사분열률(10 high power field에서 4 개 이상의 유사분열)이 고립성 섬유종의 악 성화 가능성을 나타낸다고 하였다. ${ }^{11)}$ 또한 조직 소견상 침윤 성 경계, 괴사, 출혈도 악성의 가능성을 나타낸다. ${ }^{2)}$ 이러한 기 준으로 볼 때, 본 증례에서는 세포 밀도가 낮았고, 유사분열 수는 10 high power field에서 0 1개였으며, 경계가 뚜렷하 고 출혈 및 괴사의 소견이 없어 악성의 가능성은 낮을 것이 라고 판단하였다.

치료는 종물을 수술적으로 완전히 절제하는 것이다. 고립 성 섬유종은 악성 및 재발의 가능성이 있으므로, ${ }^{5)}$ 가능하면 수술적으로 완전히 절제를 해야 한다.") 또한 종양의 크기가 $5 \mathrm{~cm}$ 이상이거나 불완전하게 절제된 경우, 혈관이나 신경 침 범 소견이 있는 경우에는 특히 악성 및 재발의 가능성이 높 으므로, 수술 후 방사선 치료를 고려해야 한다. ${ }^{12)}$

본 증례에서는 종물의 수술적 완전 절제 이후 추가적인 처 치를 시행하지 않았다. 9 개월간 재발 소견 없이 경과 관찰 중 이며, 재발의 가능성이 있으므로 지속적으로 추적 관찰 중이 다. 고립성 섬유종은 외이도에서 매우 드물게 발생하므로 앞 으로 추가적인 증례 발표와 연구가 이루어져야 할 것이며, 이 를 통해 조기에 진단과 치료가 이루어질 수 있을 것이다. 최근 저자들은 이를 치료한 경험을 문헌 고찰과 함께 보고하는 바 이다.

\section{Acknowledgments}

None.

\section{Author Contribution}

Conceptualization: Yunsuk An. Writing — original draft: Kyuha Shin. Writing - review \& editing: Juchang Kang, Kyewon Kwon, Yunsuk An.

\section{ORCIDs}

Yunsuk An

https://orcid.org/0000-0002-8570-2938

Kyuha Shin

https://orcid.org/0000-0002-3121-6993

Juchang Kang

\section{REFERENCES}

1) Klemperer P, Rabin CB. Primary neoplasms of the pleura. A report of five cases. Am J Ind Med 1931;11:385-412.

2) Daigeler A, Lehnhardt M, Langer S, Steinstraesser L, Steinau HU, Mentzel T, et al. Clinicopathological findings in a case series of extrathoracic solitary fibrous tumors of soft tissues. BMC Surg 2006;6:10.

3) Gold JS, Antonescu CR, Hajdu C, Ferrone CR, Hussain M, Lewis $\mathrm{JJ}$, et al. Clinicopathologic correlates of solitary fibrous tumors. Cancer 2002;94(4):1057-68.

4) Cox DP, Daniels T, Jordan RC. Solitary fibrous tumor of the head and neck. Oral Surg Oral Med Oral Pathol Oral Radiol Endod 2010; 110(1):79-84.

5) Rezk S, Yousef M, Zamansky M, Khan A. Solitary fibrous tumor of the auditory canal. Arch Pathol Lab Med 2004;128(12):e169-71.

6) Izumaru S, Yoshida Y, Nakashima T. A solitary fibrous tumor in the external auditory meatus. Auris Nasus Larynx 2004;31(1):65-7.

7) Lee CK, Lee HJ. Is a Solitary fibrous tumor in the external auditory canal benign? J Audiol Otol 2016;20(2):120-2.

8) Yuzawa S, Tanikawa S, Kunibe I, Nishihara H, Nagashima K, Tanaka S. A case of giant cell-rich solitary fibrous tumor in the external auditory canal. Pathol Int 2016;66(12):701-5.

9) Jefferson RC, Luz MF, Harold T, Rafael RC. Solitary fibrous tumor/ hemangiopericytoma of the external auditory canal. Acta Otolaryngol Case Rep 2019;4(1):13-6.

10) Ganly I, Patel SG, Stambuk HE, Coleman M, Ghossein R, Carlson D, et al. Solitary fibrous tumors of the head and neck: A clinicopathologic and radiologic review. Arch Otolaryngol Head Neck Surg 2006;132(5):517-25.

11) Chan JK. Solitary fibrous tumour--everywhere, and a diagnosis in vogue. Histopathology 1997;31(6):568-76.

12) Yang XJ, Zheng JW, Ye WM, Wang YA, Zhu HG, Wang LZ, et al. Malignant solitary fibrous tumors of the head and neck: A clinicopathological study of nine consecutive patients. Oral Oncol 2009;45(8):678-82. 